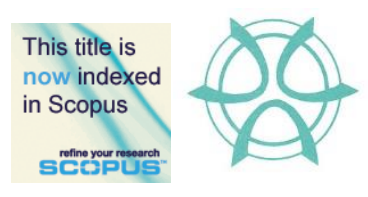

PLANNING MALAYSIA:

Journal of the Malaysian Institute of Planners

VOLUME 16 ISSUE 1 (2018), Page $334-347$

\title{
HOUSE PRICE MOVEMENT FOR PRIMARY AND SECONDARY MARKETS: EVIDENCE FROM SELANGOR, MALAYSIA
}

\author{
Haszlila Jalil ${ }^{1}$, Norngainy Mohd Tawil ${ }^{2}$, Md Nasir Daud $^{3}$, \& Aina Edayu Ahmad ${ }^{4}$ \\ ${ }^{1,2}$ Faculty of Engineering and Built Environment, \\ UNIVERSITI KEBANGSAAN MALAYSIA \\ ${ }^{3}$ Faculty of Built Environment \\ UNIVERSITI MALAYA, MALAYSIA \\ ${ }^{4}$ Valuation and Property Services Department \\ NATIONAL PROPERTY INFORMATION CENTRE
}

\begin{abstract}
The aim of this study is to determine the trend of escalation for both primary and secondary housing units. This research applies the desk study approach which uses secondary data from statistical format, which is the property market report (PMR) from the year of 2004 to 2014. Data from the PMR was analysed by using descriptive statistics method which provides a general overview of the house price movement. The observation only focuses the house price movement from the (9) districts in Selangor state. Results show that even though the volume of transactions decreases, the prices of residential properties are steadily increasing which also indirectly escalates the secondary market price.
\end{abstract}

Keywords: house price, price escalation, primary market, secondary market 
PLANNING MALAYSIA

Journal of the Malaysia Institute of Planners (2018)

\section{INTRODUCTION}

Dwelling is the most important asset for every individuals to develop social and family activities. Dwellings can generate income through rental, lease and investment. These activities lead to the stability of the market from the real estate perspectives. Rising house prices will provide high returns to investors but also leave negative impacts on buyers who want to own their dream houses. With current economic situation and strict terms from financial providers, it is getting difficult for individual to own their dream house.

The balance between the supply and demand for housing is important in dealing with price stability in the residential property market (Haron \& Liew, 2013). The price for house units will remain low if the county develops excessive new development, while for not-so-new development, it will lead to a rise (Glaeser, Gyourko, \& Saks, 2005). However, the growth in the residential property market is important to the national economy (BNM, 2013). The growth of population increases the demand for housing especially in the Klang Valley (C H Williams Talhar \& Wong, 2014). This scenario creates urbanization and subsequently affect house prices (Hashim, 2000). The transportation routes and easy accessibility influence the prices of residential properties (Adair, McGreal, Smyth, Cooper, \& Ryley, 2000). Additionally, neighbourhood facilities such as the recreational and shopping areas also affect the house price (Ding \& Knaap, 2003; So, Tse, \& Ganesan, 1997).

In this research, the movement of the residential property prices were analysed based on the primary market transactions set up by the developers and secondary market transactions which were recorded by the National Property Information Centre (NAPIC) from year 2004 to 2013. Primary market is the price which was set by the developers, which means that the transaction is between the developers and first house buyers. It represents the first transaction for the new development. On the other hand, the secondary market refers to sub sale, which indicates that the price is set by individuals based on the current market transaction. It can be the second, the third or later subsequent of transactions in the market (NAPIC, 2014).

The scope of the research only focuses Selangor as it is the state with the highest population in Malaysia. According to 2014 Property Report by Zaki and Partners, Selangor is one of the most attractive and developed states besides Kuala Lumpur and Johor. The researchers will observe the movement of prices and volume of transactions by district and type of residences for the year 2004 to 2013.

\section{SELANGOR HOUSING MARKET}

Selangor has the highest population in Malaysia, with approximately 5.46 million people. With an area of 7,900 square kilometres with a density of 526 persons per square kilometre, Selangor became a favourable place for migration. According 
Haszlila Jalil Norngainy Mohd Tawil, Md Nasir Daud, \& Aina Edayu Ahmad

House Price Movement for Primary and Secondary Markets: Evidence from Selangor, Malaysia

to the 2010 statistics from the Department of Statistics, 20 to 29 years group of ages constituted the largest group, which represents $23 \%$ of the total population in Selangor. This is most probably due the job opportunities, educational centres and other activities that attract such young group of people.

The attractions have led to the increased numbers of density in Selangor, along with the residential development. The increasing commercial activities such as shopping complexes, industrial and trading also influence the increased number of migration to Selangor. Thus, demand for residential is gradually increasing to fulfil the needs for dwelling. Figure 1 shows the state-by-state ofimmigrant population for the 2012 to 2013 and the 2013 to 2014 .

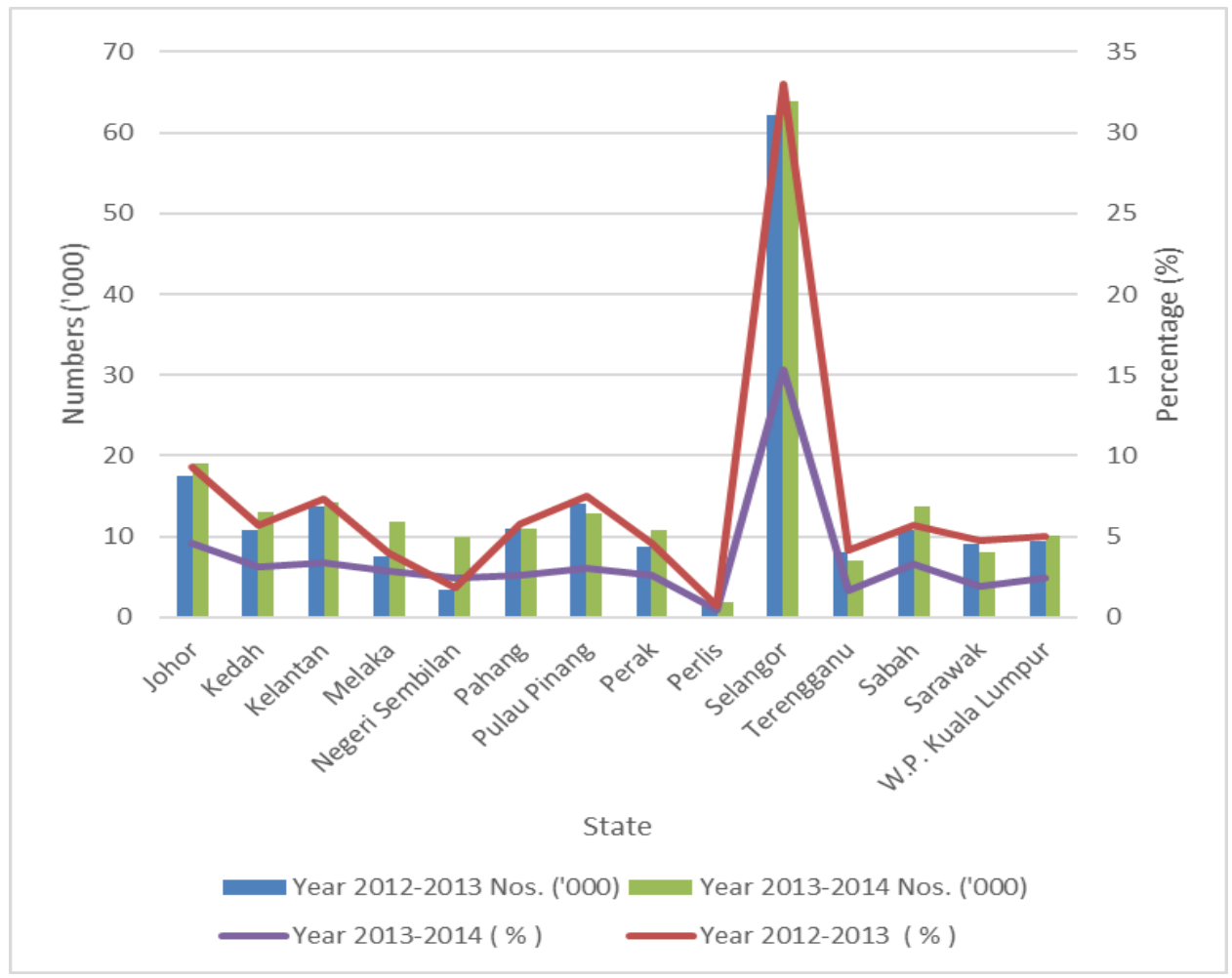

Figure 1: Immigrants by state, Malaysia, 2012-2013 \& 2013-2014

Source: Jabatan Perangkaan Malaysia (2015) 
Journal of the Malaysia Institute of Planners (2018)

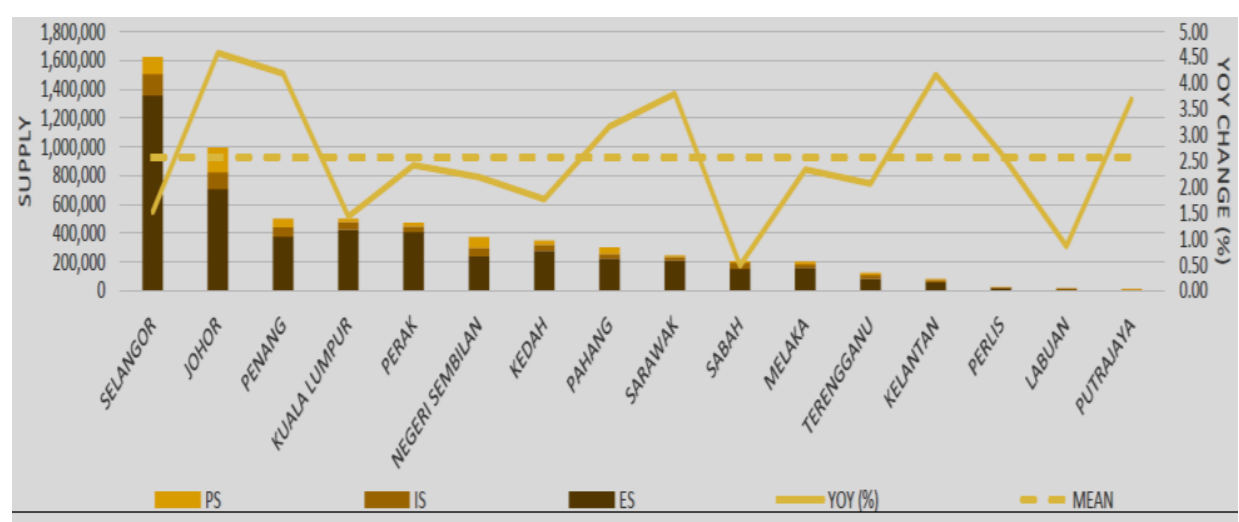

*ES = Existing Stock * "IS = Incoming Supply *PS = Planned Supply

Figure 2: Supply compilation of residential properties in Malaysia, 2013 Source: NAPIC (2014)

Figure 2 shows that Selangor was the highest existing stock of residential properties $(1,358,054: 29 \%)$, also with the highest number of incoming supply $(149,644: 21 \%)$ and second highest number in planned supply (116,881:19\%). In terms of the property market, the state of Selangor had recorded 64,269 units of transactions comprising of $26.1 \%$ of the residential sub-sector in Malaysia (NAPIC, 2014). Figure 3 shows the breakdown on property transactions by all states for 2013.

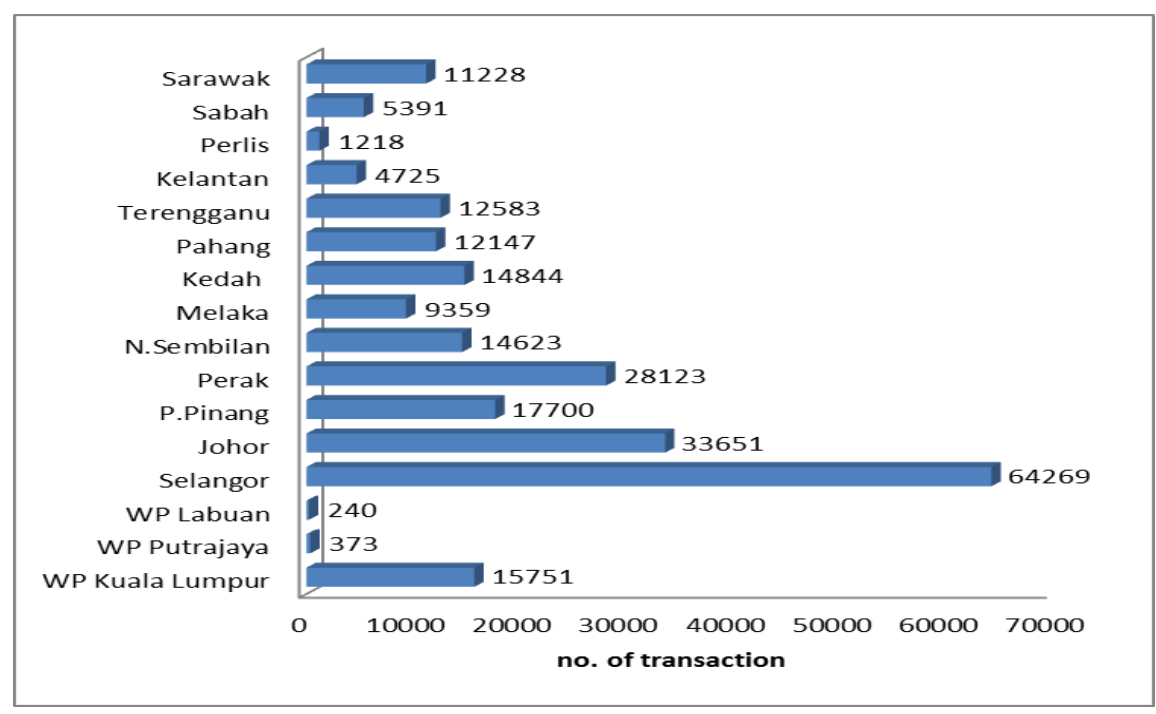

Figure 3: Breakdown on volume of transaction by state, 2013

$$
\text { Source: NAPIC (2014) }
$$


Haszlila Jalil Norngainy Mohd Tawil, Md Nasir Daud, \& Aina Edayu Ahmad

House Price Movement for Primary and Secondary Markets: Evidence from Selangor, Malaysia

According to NAPIC (2014), house prices generally remained unchanged for the year 2014, as new housing estates proliferated around neighbourhood amenities such as the KTM commuter stations, Rawang Bus Terminal, Rawang AEON and TESCO hypermarkets, and around highways such as Shah Alam Highway (KESAS), New Klang Valley Expressway (NKVE), New Pantai Expressway (NPE), Lebuhraya Damansara-Puchong (LDP) and the Federal Highway. However, house prices are expected to rise along with the increasing costs of raw materials and lands which then led in the increase of development costs. Moreover, primary market price will keep rising and this scenario will have certain impact to the secondary market price. Market analysts involved in the real estate industry anticipate that house prices in secondary market will continue to rise if the supply of affordable houses is decreasing as developers prefer to provide high-end products with high marginal return.

\section{METHODOLOGY}

\section{Data Collection}

This research applies the desk study approach which use secondary data from statistical format, which is the property market report (PMR). The word statistical refers to official statistics collected by NAPIC to provide information on market transacted house price. For this research, the researchers use reports of property market transaction from year 2004 to 2013. The researchers intended to observe the house price movement of (9) districts in Selangor state. The PMR presents two sets of data, i) primary residential houses transacted price and ii) secondary residential houses transacted price.

\section{Data Analysis}

Data from the PMR will be analysed by using descriptive statistics method which provides a general overview of the house price movement. The data is presented in the form of tabulation such as the bar charts, pie charts and graphs.

\section{FINDINGS ON THE MARKET EVIDENCE}

Selangor comprises nine (9) districts, namely Gombak, Hulu Langat, Hulu Selangor, Klang, Kuala Langat, Kuala Selangor, Petaling, Sabak Bernam dan Sepang. From the analysis, the districts of Petaling, Klang and Hulu Langat are active in buying and selling residential properties. Petaling is the prime area of the city centre and known to have high population density.

Figure 4 shows the percentage of transaction for the year 2013 by District in Selangor. The Petaling district is the most active area with $37.1 \%$ followed by the district of Hulu Langat (22.5\%), Klang (14.4\%) and Gombak (11.9\%). 
PLANNING MALAYSIA

Journal of the Malaysia Institute of Planners (2018)

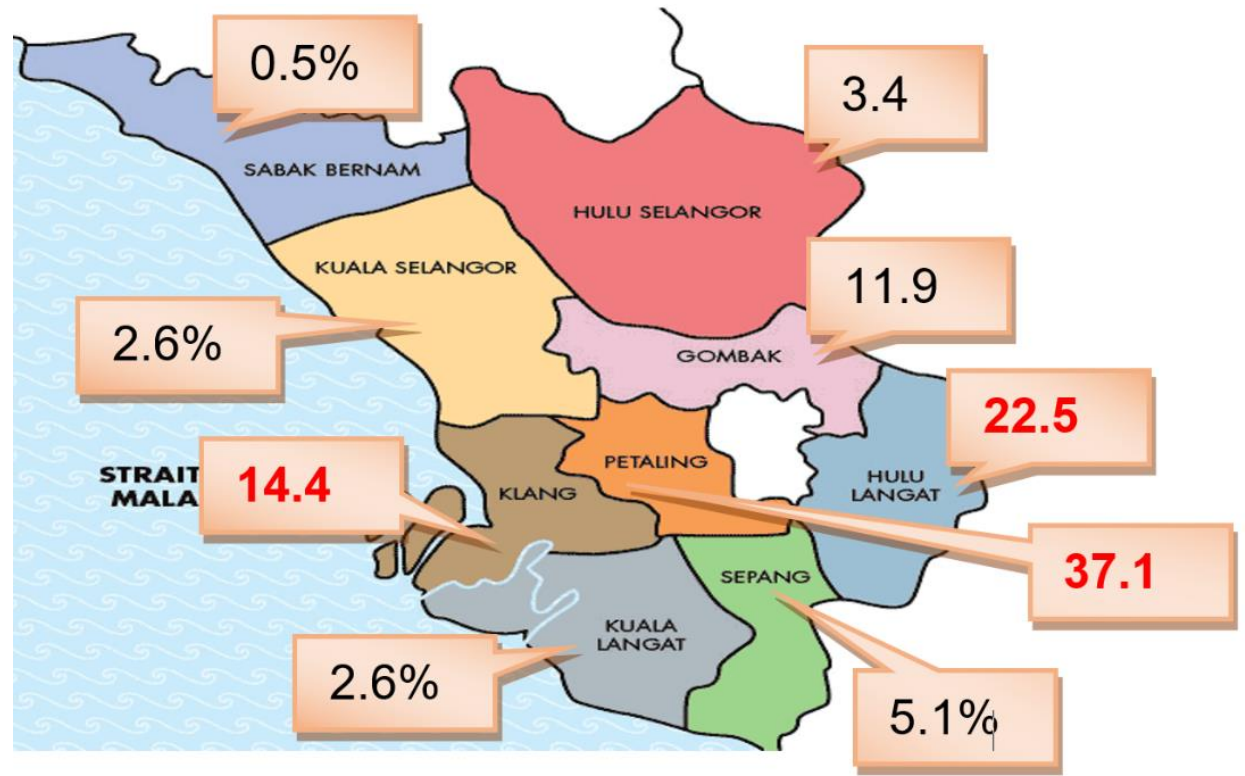

Figure 4: Breakdown of the percentage of transaction by district in Selangor Source: NAPIC (2014)

\section{Volume of Transactions by District}

Figure 5 displays the uncertain volume of transactions in the primary market. The primary market comprises of the housing schemes newly developed and launched, and prices set by the developers. Supply of new units slackened in year 2007 and took an even greater deceleration in year 2008 before bouncing back in year 2010, a phenomenon attributable to the global economic crisis. The district of Hulu Langat was affected badly from year 2009 to year 2010 but subsequently showed some progress in year 2011 and year 2012. Records also showed significant reduction for most of the districts in the year 2013. 
Haszlila Jalil Norngainy Mohd Tawil, Md Nasir Daud, \& Aina Edayu Ahmad

House Price Movement for Primary and Secondary Markets: Evidence from Selangor, Malaysia

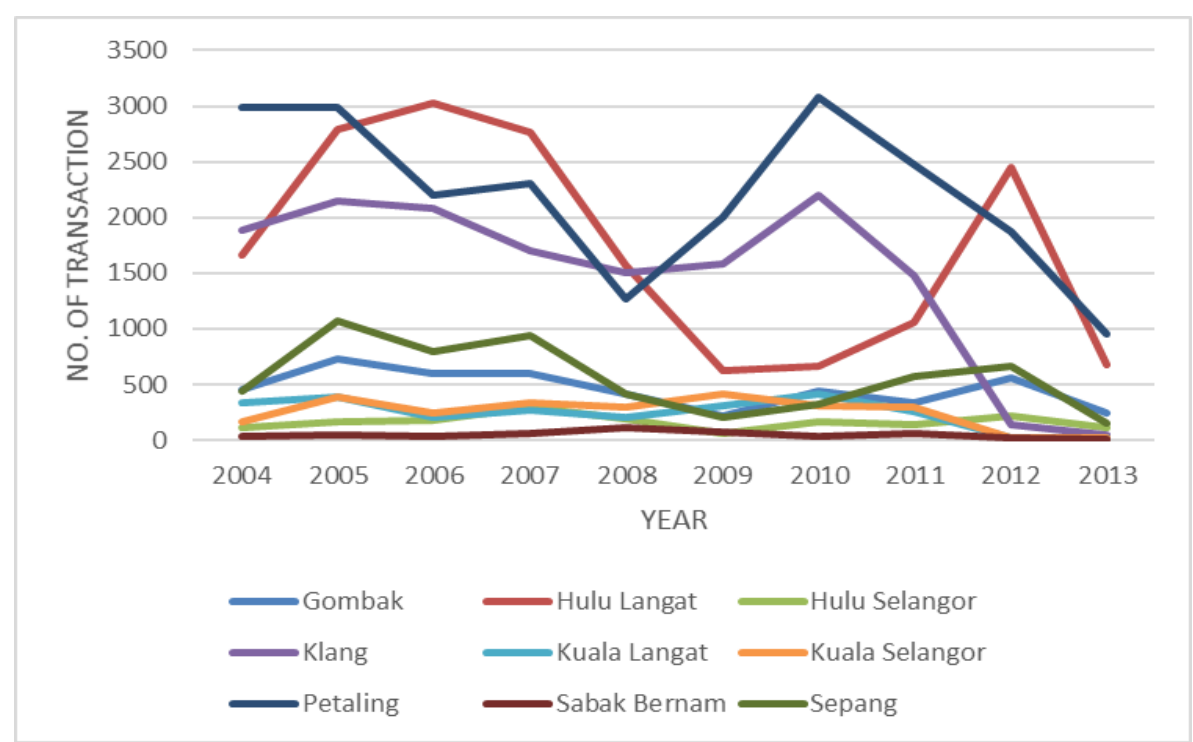

Figure 5: Volume of transaction of primary market

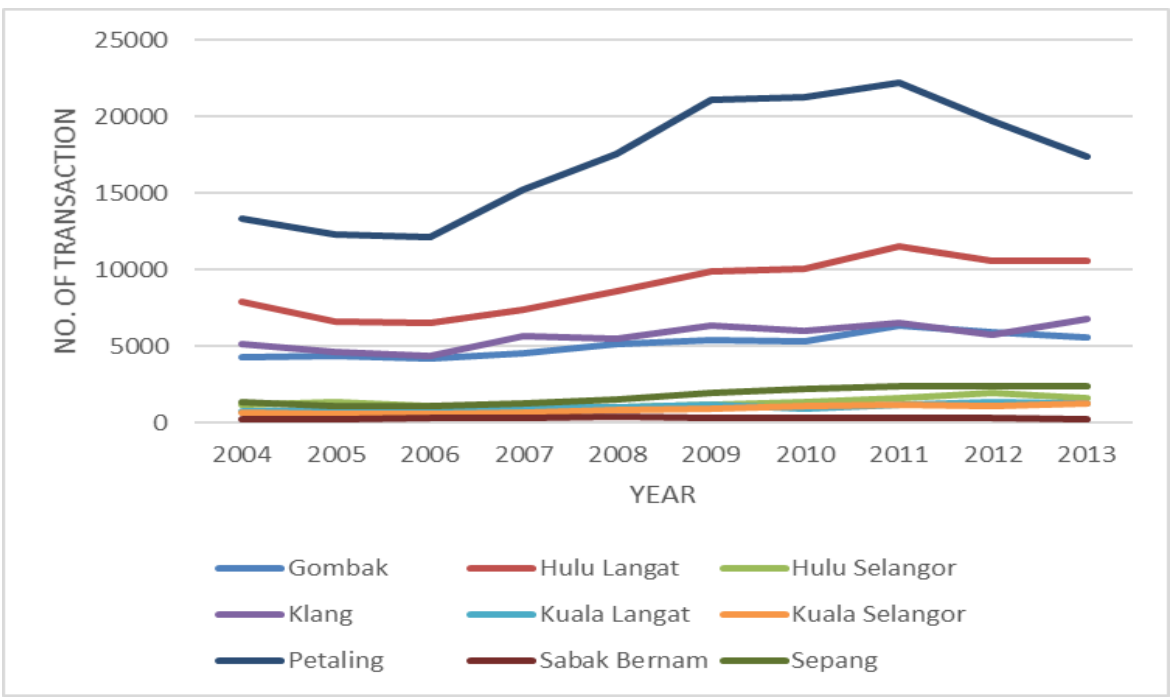

Figure 6: Volume of transaction of secondary market

Equally important, the primary market graph showed quick decrease and increase from year 2008 to year 2010. The conditions was because of the two economic packages that were introduced in November and March 2008 (Hashim, 2010). These packages had been allocated mostly to infrastructural projects including the building of low and medium-cost houses. 
PLANNING MALAYSIA

Journal of the Malaysia Institute of Planners (2018)

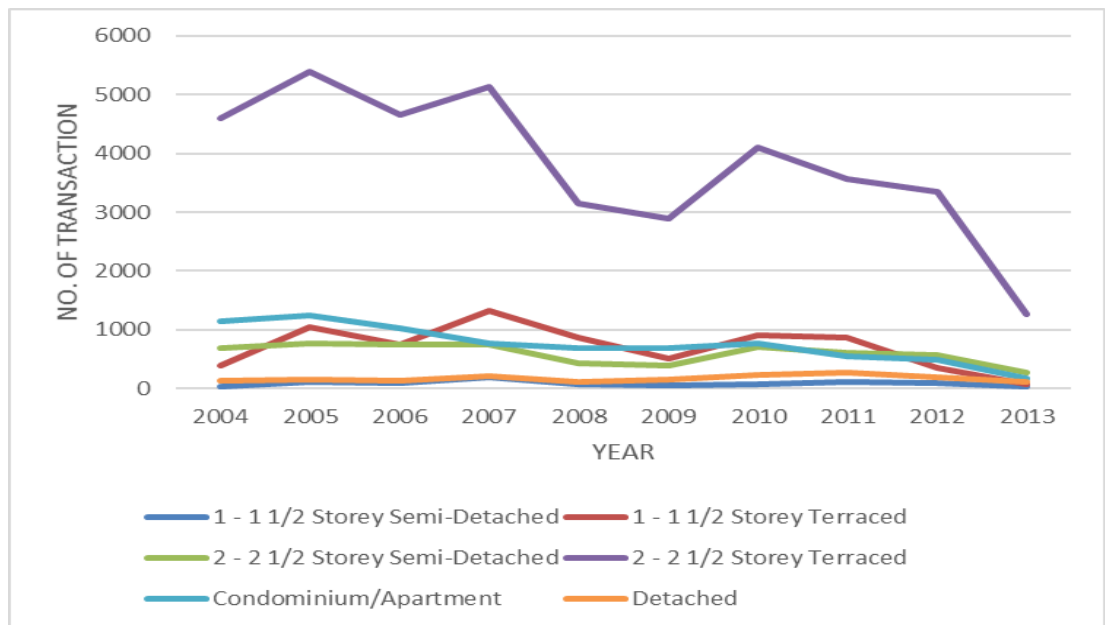

Figure 7: Movement of primary market transaction by type of residential property

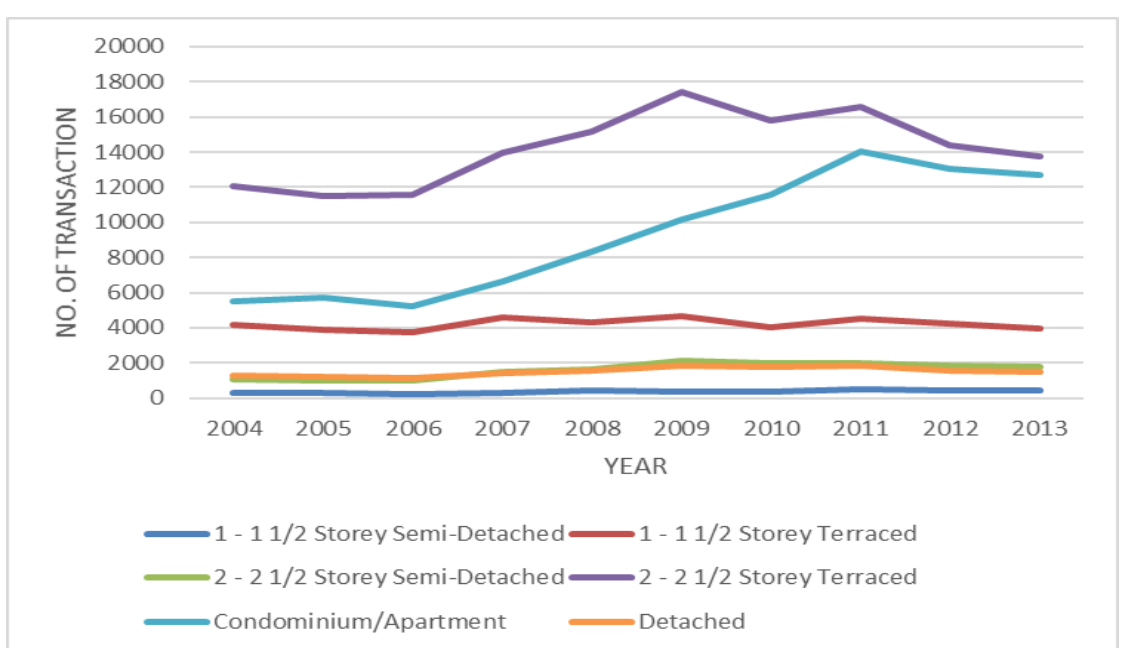

Figure 8: Movement of secondary market transaction by type of residential property

The construction sector was most likely to benefit from the stimulus package. As a contradiction, the secondary market of buying and selling homes, also known as sub sale, or the flow of its transactions showed a slight decrease in year 2005 and year 2006. The market shows rapidly increased in year 2007 and onwards until year 2012. The increase was due to the exemption of Real Property Gain Tax (RPGT) which took effect on 1 April 2007. There was an exception for newly launched products and the exemption of the RPGT would only affect the secondary market. However, this exercise would spur more activities of profitable property transactions. 
Haszlila Jalil Norngainy Mohd Tawil, Md Nasir Daud, \& Aina Edayu Ahmad

House Price Movement for Primary and Secondary Markets: Evidence from Selangor, Malaysia

Both graphs showed that the volume of transactions on the secondary market was not affected regardless of the uncertain flow for the primary market. As compared to the primary market, the secondary market in Selangor remained active with an upward movement observed in the transaction volume of the properties.

\section{Volume of Transactions by Type of Residential Property}

For the primary market, the residential terrace houses of 2-2 1/2 storey represented the highest transaction in the year 2004 and year 2013 which also applicable for the secondary market. Although more attractive and relatively affordable condominiums were being launched in the market, landed residential properties remained the preferred choice of accommodation by the Selangor residents.

Despite of that, multi-storey dwellings such as condominium and apartment showed a significant rise in the year 2008-2011 for secondary market although the movement was expected to be static in the primary markets. Huge escalation in prices of landed property may serve as the main reason and lead buyers to purchase condominiums or apartments.

In relation with migration, most of whom were young and in a small number of families and categorised as a middle-income earner. The multi storey residential was the suitable type for them to reside. Economic crisis was also one of the factors which financial institution bit stringent in providing financial support to the youngsters. Percentage of migration which most of whom were middle-income earners become a primer to purchase multi-storey dwelling. Aside from that, incentive from financial institution and huge reduction in supply of landed properties may also be one of the reasons. Developers also took advantage by delaying the constructions of landed property and focusing on developing high rise residential property.

\section{Volume of Transactions for Double Storey Terrace House}

Within residential market, transaction activity is generally higher for $2-21 / 2$ storey terrace houses compared to other types. The chart showed that the volume of transactions for the secondary market was higher than the primary market. This might be due to the availability of secondary houses in the market compared to primary houses which were subject to supply and completion by the developers. During the economic crisis in 2007, transaction activity in the secondary market continued to grow while the transaction for the primary market was seen to decline. 
PLANNING MALAYSIA

Journal of the Malaysia Institute of Planners (2018)

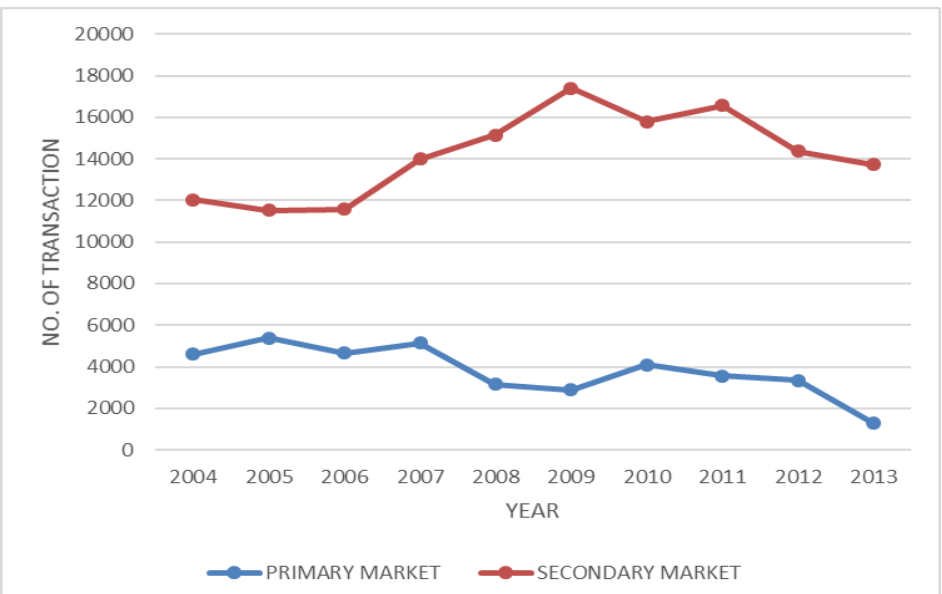

Figure 9: Movement of volume of transaction for double storey terrace house

\section{Price Movement - Type of Property}

Based on the analysis, three types of houses with active escalation in prices observed comprised of detached, 2-2 $\frac{1}{2}$ storey semi-detached and 2-21/2 storey terraced houses.

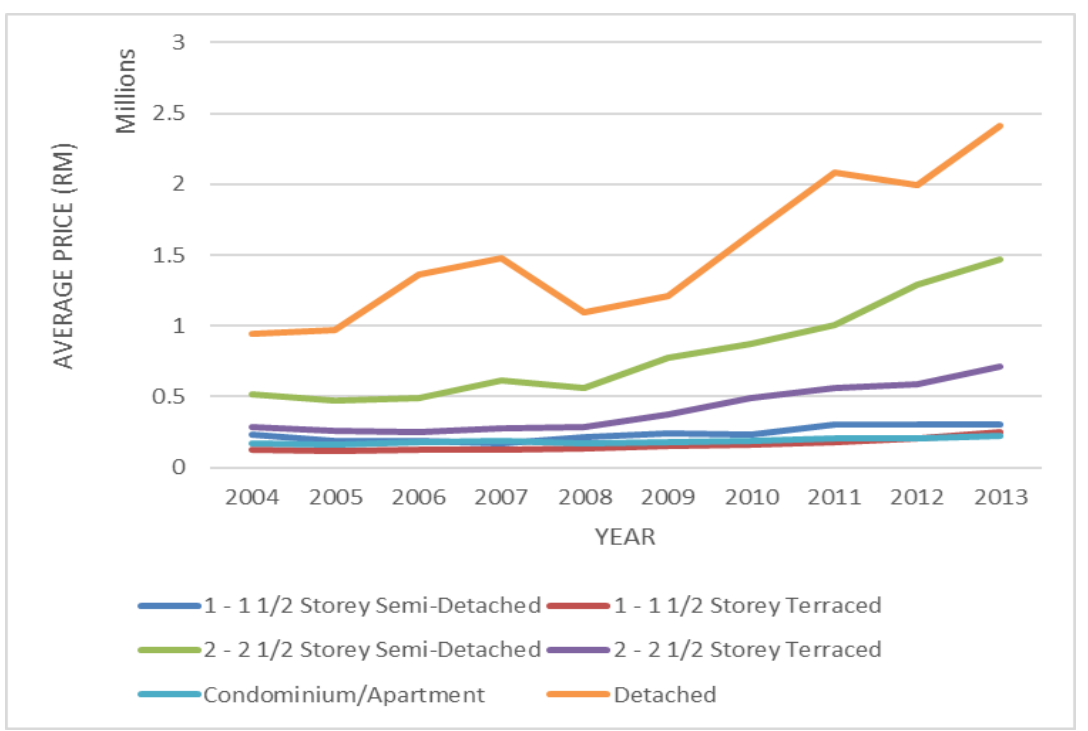

Figure 10: Trend of average price of primary market by type of residential property 
Haszlila Jalil Norngainy Mohd Tawil, Md Nasir Daud, \& Aina Edayu Ahmad

House Price Movement for Primary and Secondary Markets: Evidence from Selangor, Malaysia

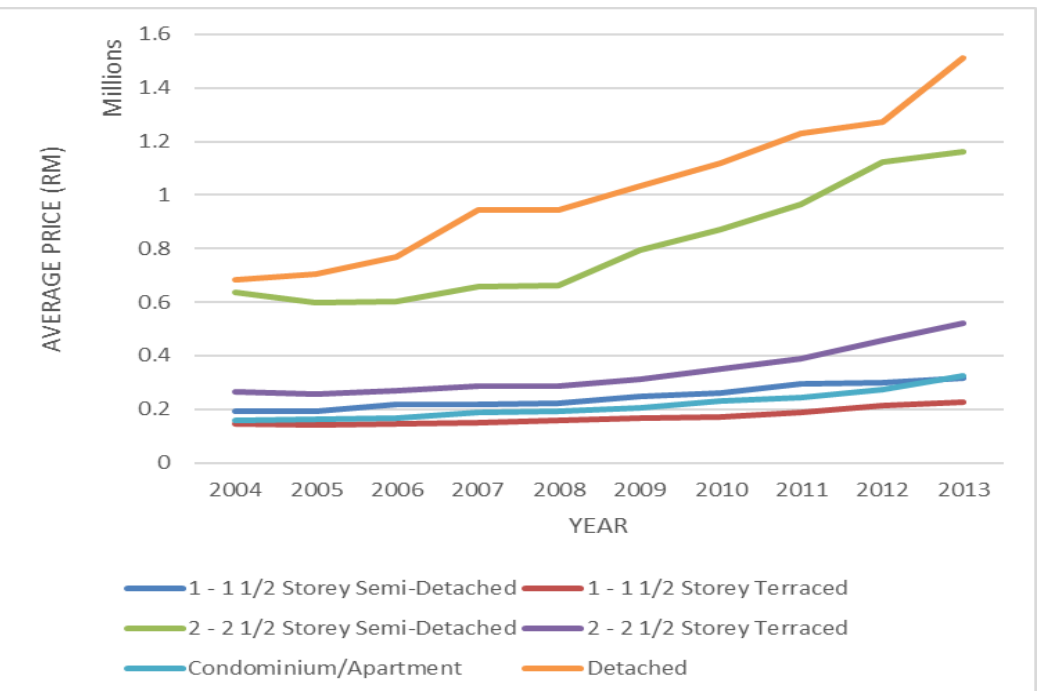

Figure 11: Trend of average price of the secondary market by type of residential property

The price for detached house showed escalation at approximately $150 \%$ with average price reaching almost RM2.5 million in the year 2013 compared to less than RM1.0M in 2004. Double storey terrace houses also showed escalation with $150 \%$ reach until RM700, 000.00. Highest risen price was recorded by semidetached house with approximately $200 \%$ increment in 10 years. While the other types of homes demonstrated slow growth. The flow of the average house prices by type of residence can be referred in the figure 10 above for the primary market.

The secondary market also shows the detached houses, double storey semi-detached and double storey terraces are active in price escalation. From the analysis, detached houses increased up to $120 \%, 80 \%$ for semi-detached and almost $100 \%$ for $2-2 \frac{1}{2}$ storey terrace houses. Figure 11 shows the trend of average price of the secondary market by types of residential properties. 


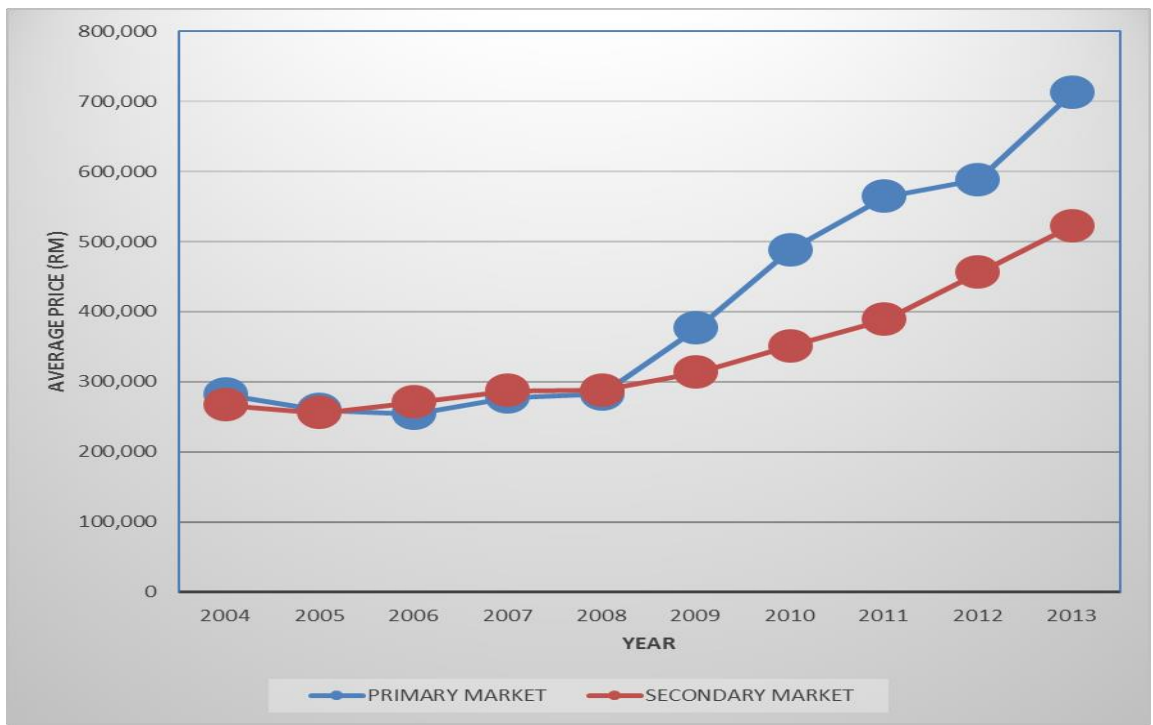

Figure 12: Trend of average price for double storey terrace

Figure 12 above represents the price trend for double storey terrace house in Selangor. It shows that both primary and secondary markets were stable, beyond RM300, 000 for the year 2004-2008. However, a slight movement was observed in the middle of 2008. The price in the primary market increased to RM700,000 in year 2013 while in the price in secondary market went up to RM500,000 in year 2013.

From the graph and analysis, it is safe to conclude that the price determined by the developer for the new development will bring a positive impact on the secondary market price.

\section{CONCLUSION}

From the analysis, it is evidenced that even though the volume of transactions decreased, prices of residential properties were steadily increasing. This escalation indirectly affects the secondary market price mostly for high-end and medium residential homes.

In the face of economic difficulties, prices for residential property tend to be fall-resistant and are more likely to remain unchanged compared to the commercial property as well as equity. In many cases, movement in residential housing market will contradict the volume of transactions compared to prices since property owners will not sell their properties at low price (Zhu, 2005).

Developers also have exclusive rights to determine the flexi price rather than seller in secondary market and able to encourage homebuyers to purchase house above market value. Developers also offer "bulk purchase" for oversupply scenario, with attractive package, below the market or at cost price. 
Haszlila Jalil Norngainy Mohd Tawil, Md Nasir Daud, \& Aina Edayu Ahmad

House Price Movement for Primary and Secondary Markets: Evidence from Selangor, Malaysia

Developers will slow down their activities to ensure that the completed residential schemes developed are fully sold. With the existing price of primary market, most future purchasers would move to secondary market to purchase their property. Small family may prefer the primary market for modern concept and design. As for aged family, they would divert their intention taking into consideration cost of living, hence settled with residential in the secondary market. Secondary market becomes an option due to the accessibility neighbourhood scheme, recreational and others.

As of the current scenario, most of immigrants in Selangor are categorized under the middle-income earners, thus, they prefer to invest in secondary market. The above facts show that secondary market is growing in line with the movement of price for primary market. It is then concluded that the price movement in secondary market is affected by price escalation in primary market, demand from middle-income earners as well as immigrants, high population area, and readiness of completed infrastructure to reach the housing area. Most of secondary market areas had been fully equipped with modern infrastructure, schools, complexes and even higher education institutions and market analysts opine that those infrastructures will boost the secondary market up.

The future exercise will focus on the factors which will directly influence the escalation of price, particularly in the secondary inactive market. These factors will be identified through surveys with respondents being buyers or potential buyers, real estate agents and appraisers in areas identified as inactive areas. The government will utilise the findings to re-develop those inactive areas to resolve the issue of house ownership in Malaysia. 
PLANNING MALAYSIA

Journal of the Malaysia Institute of Planners (2018)

\section{REFERENCES}

Adair, A., McGreal, S., Smyth, A., Cooper, J., \& Ryley, T. (2000). House prices and accessibility: The testing of relationships within the Belfast Urban Area. Housing Studies, 15(5), 699-716.

Bank Negara Malaysia [BNM] (2013). Laporan kestabilan kewangan dan sistem pembayaran 2012.

C H Williams Talhar \& Wong. (2014). WTW market report 2014.

Ding, C., \& Knaap, G. J. (2002). Property values in inner-city neighbourhoods: The effects of homeownership, housing investment, and economic development. Housing Policy Debate, 13(4), 701-727.

Glaeser, E. L., Gyourko, J., \& Saks, R. E. (2005). Why have housing prices gone up? American Economic Review, 95, 329-333.

Haron, N. A., \& Liew, C. (2013). Factors influencing the rise of house price in Klang Valley. International Journal of Research in Engineering and Technology (IJRET), 2(10), 261-272.

Hashim, Z. (2000). Pembandaran dan kenaikan nilai harta tanah di Malaysia. Akademika, 5(1), 27-46.

Jabatan Perangkaan Malaysia (2015). Laporan penyiasatan migrasi, Malaysia 2014. Putrajaya: Jabatan Perangkaan Malaysia.

National Property Information Centre [NAPIC] (2014). Laporan pasaran harta tahunan.

So, H. M., Tse, R. Y. C., \& Ganesan, S. (1997). Estimating the influence of transport on house prices: Evidence from Hong Kong. Journal of Property Valuation and Investment, 15(1), 40-47.

Zhu, H. (2005). The importance of property markets for monetary policy and financial stability. Real Estate Indicators and Financial Stability, 21, 9-29. 